\title{
The Use of Meme Pictures to Improve the Writing Creativity
}

\author{
Boris Ramadhika ${ }^{1}$ \\ \{ggramadhika@untidar.ac.id\} \\ ${ }^{1}$ Universitas Tidar,Magelang, Indonesia
}

\begin{abstract}
This action research aimed to improve the writing creativity using meme pictures. It was conducted in two cycles with three meetings each. The main subjects were 34 students of Grade XI MIPA 3 SMA N 1 Temanggung in the academic year of 2016/2017. The research data were quantitative (pre-test, Cycle I and Cycle II writing tests, and Brain Quotient test) and qualitative (the interview transcripts and field notes of the observations) in nature. Trustworthiness was achieved through triangulation. The fact that students scoring high in BQ test was also performing good in their writing performance. The improvement of the students' writing was indicated by the increase of their mean scores of writing from 62.96 in the pre-test to 79.54 in the post-test; with the Cohen's Kappa was 0,677. It was also supported by the result of Wilcoxon signed-rank-test, which was 0,000 .
\end{abstract}

Keywords: memes, writing creativity

\section{INTRODUCTION}

As a widely used international language, English has been taught as one of the compulsory subjects in formal schools in Indonesia. Writing, as one of the productive skills, has many benefits. Writing as a foreign language can be beneficial in developing learners' ability to construct ideas, thought, and feeling [1]. Moreover, learners can also improve their communicative ability. Writing also enables them to express their thoughts or in other words, imaginative worlds which sometimes cannot be expressed orally. Speaking of imaginative worlds, the term' writing creativity' suggests imaginative tasks using their creativity [2].

However, writing is also considered as one of the most challenging skills since many aspects have to be mastered. Those aspects containing in writing skill are such as writing mechanics, vocabulary mastery, grammatical rules, contents, creativity, and issues of the letter, word, and text formation [2]. The problems were found after observing and interviewing the English teacher and some students in SMA N 1 Temanggung, especially eleventh-grade students. The first problem the writer found was the lack of the students' writing creativity. According to the writer's observation, the time given for practicing writing was limited, which made the students had no proper time for practicing writing creativity. 
Another problem found based on the interview with the teacher. She stated that the students seemed confused during the writing process and could not express their ideas smoothly. They could not generate their ideas and often got confused in choosing words that could represent the ideas they wanted to write in English.

Additionally, when the writer asked the students whether they wanted to continue their study at a university or not, they mostly said yes. It was a concern they had to know that at the university, almost all things should be done independently. As a result, one of the matters was that the students' writing creativity should be good. Creativity in writing is a journey of self-discovery, and self-discovery promotes effective learning [2]. Moreover, The curriculum 2013 in Indonesia prepares students to have the skills, one of which is creativity. Thus, creativity is an important aspect of the current curriculum.

As had been stated before, the writing creativity of the eleventh-grade students of SMA N 1 Temanggung is still low. In order to solve the problems, the writer used pictures, specifically meme pictures. The word 'meme 'originally came from a biologist who defines memes as a unit of cultural knowledge that is passed between people and reprinted [3]. The choice of meme pictures was based on its viral phenomena among teenagers in the world, including Indonesia. It could be seen from social media of Indonesian people such as facebook, twitter, and Instagram, which contain lots of meme pictures. Also, meme pictures are part of internet memes which contain funny pictures imitating the real-life related to most human social life [4].

In the case of academic purposes, the use of meme pictures can also be used as the materials to improve the students' writing creativity. Since later many university writing creativity courses place an equal emphasis on the study of literature and the practice of writing [5], the ability of creativity in writing will be beneficial later in the 21 st century. Using memes can also awareness of socio-political issues, dialogic argumentation, and engagement through multiliteracies in the outputs [6].

Moreover, it is believed that facilitating students to improve their creativity makes them have many benefits. They could get many benefits, such as increasing their confidence, motivation, and positive attitude towards writing. They also can freely express their ideas as well as to maximize the opportunities to have fun [7]. It is also supported by the statement that the critical characteristics of meme pictures are humor, playfulness, and ability to engage the hosts (creators) in a creative way [4]. This can be done with the use of the memes, which made them to freely write their ideas, thoughts, or experiences through their writing.

Utilizing memes can also make students creative and innovative. Memes creation proposes an eye-catching learning process that can be easily adopted by students [8]. Memes can also lead to better community engagement [9] and potentially be used to have creative networks which create behavior and opinions [10].

Therefore, considering the benefit of creative thinking as well as writing creativity, the writer was interested in conducting action research for the eleventh-grade students of SMAN 1 Temanggung through the use of meme pictures.

\section{METHOD}

This research is an action research using Kemmis and McTaggart model (2000). The writer maintains a spiral of self-reflective spirals of planning a charge, acting and 
observing the processes and consequences of the change, reflecting on these processes and consequences and then replanning, acting and observing, reflecting, and so on.

This research is an action research using Kemmis and McTaggart model [11]. The writer maintains a spiral of self-reflective spirals of planning a charge, acting and observing the processes and consequences of the change, reflecting on these processes and consequences and then replanning, acting and observing, reflecting, and so on.

The research was carried out in SMAN 1 Temanggung, which is located in Kartini Street number 4 Temanggung, Central Java. The main subject of this research was the students of class XI IPA 3 of SMAN 1 Temanggung in the academic year of 2016/2017. There were 34 students with 10 males and 24 females. Also, a collaborator from a friend of the writer and the English teacher acted as the collaborators. The research was carried out in the first semester of academic year 2016/2017, from August 23rd to October 1st. It followed the school calendar and the schedule in which the English subject is taught.

Two types of data were obtained in this research. The first one was quantitative data which was obtained from students' scores of the writing tests (pre-test and post-test which is the same as cycle II test) and from students' scores in brain quotient assessment. To analyze the quantitative data, the writer used the writing assessment adapted from CEFR to measure the students' scores. Meanwhile, the qualitative data was obtained from observations and interviews. To analyze the data, the writer adapted the stages from [12], which were consisting of data reduction, data display, and conclusion drawing and verification.

Furthermore, to verify the data, the writer did some actions. The quantitative data was verified by implementing the interrater reliability of Cohen's Kappa to measure the degree of consensus between two judges in measuring the students' scores. Meanwhile, for the qualitative data, the writer verified using data validity and triangulation.

\section{RESULT AND DISCUSSION}

The research was conducted on August 27th and ended on October 4th, 2016. Its objective was to activate students' creative thinking as well as to improve students' writing creativity of grade XI D of science class. The actions were at the end, conducted in two cycles. Based on the results in both cycles, the writer, supported by the English teacher and the collaborator, decided to discontinue the research. The implementation of the actions planned both in the first and the second Cycle successfully reached the research' objectives. The students' creative thinking could be activated using the memes and was followed by their writing skill improvement, especially in writing creativity.

The actions implementation during the Cycle I and Cycle II were done thoroughly and planned in detail. The research findings showed that the implementation of the actions successfully fulfilled the research's objectives. The improvement could be seen not only from the students' scores but importantly also from other aspects as well, such as their motivation and manner. From the motivation, the students had a new experience of learning English using the memes. The teacher did also have it since she had never used the memes as her primary materials. The students especially were more active, creative, and critical. The manner also became an essential aspect since they would face many kinds of memes that were not suitable for their age (adult and violence, for example). Thus, the positive manner needed to be planted to them. The other improvement the students got was about 
their writing and writing creativity scores. Those improvements were reached by assessing them with tests.

The implementation of using memes to activate students' creative thinking as well as to improve students' creative thinking was successfully done. Not only the students had a new experience in their English learning because of the use of the memes, but also they had more writing and writing creativity practices. Moreover, by activating their creative thinking, the students' critical thinking was also activated as well. It could be seen from their critical critiques towards the bullying action and other topics as well.

Looking at the scores, the students did have some improvements. They could improve their writing scores in all aspects. However, only the writing mechanics did not improve in between the pre-test and the Cycle I Test. The following is the means from the maximum score of 4 of each aspect:

Table 1. Students' Average Scores

\begin{tabular}{|c|c|c|c|c|c|}
\hline Test & $\begin{array}{c}\text { Vocabular } \\
\mathbf{y}\end{array}$ & Text Form & $\begin{array}{c}\text { Sentence } \\
\text { Form }\end{array}$ & Grammar & $\begin{array}{c}\text { Writing } \\
\text { Mechanics }\end{array}$ \\
\hline Pre-Test & 2.56 & 2.12 & 2.56 & 2.53 & 2.75 \\
\hline Cycle I & 3.06 & 2.84 & 2.90 & 2.81 & 2.69 \\
\hline Cycle II & 3.39 & 3.33 & 3.21 & 2.90 & 3.06 \\
\hline
\end{tabular}

There were some increasements from 2.56 to 3.06 to 3.39 in terms of the mean scores. It proved that they could write the analytical exposition text well, which was used their critical and creative thinking on making it. However, there was a failure, as well. It was the students' writing mechanics that dropped from 2.75 in the pre-test to 2.69 in the Cycle I test. It was due to the lack of supporting sentences in the students' writing. Therefore, further action to give explanation related to analytical exposition text was to explain more about the supporting sentences. More exercises to make their critical and creative thinking optimally were given. As a result, in the Cycle II test, the students' writing mechanics score was increased to 3.06, which in other words, better than in Cycle I test even in the pre-test as well. By seeing at the score of the vocabulary aspect, this action was considered as the successful one. There was a significant improvement from time to time in which the scores were 2.56 to 3.06 and finally to 3.39 .

In terms of the tests scores, the students also got some improvements as well. There were significant improvements among the cycles:

Table 2. Students' Writing Tests Scores

\begin{tabular}{|c|c|c|c|c|}
\hline Scores & $\begin{array}{c}\text { Categori } \\
\text { es }\end{array}$ & $\begin{array}{c}\text { Pre } \\
- \\
\text { test }\end{array}$ & $\begin{array}{c}\text { Cyc } \\
\text { le I } \\
\text { Tes } \\
\text { t }\end{array}$ & $\begin{array}{c}\text { Cycle } \\
\text { II } \\
\text { Test }\end{array}$ \\
\hline $90-100$ & Excellent & 0 & 0 & 2 \\
\hline
\end{tabular}




\begin{tabular}{|l|l|l|l|l|}
\hline $80-89$ & $\begin{array}{l}\text { Very } \\
\text { Good }\end{array}$ & 0 & 3 & 14 \\
\hline $70-79$ & Good & 3 & 12 & 11 \\
\hline $60-69$ & Fair & 14 & 13 & 3 \\
\hline $50-59$ & Poor & 15 & 5 & 3 \\
\hline$<50$ & $\begin{array}{l}\text { Very } \\
\text { Poor }\end{array}$ & 0 & 0 & 0 \\
\hline \multicolumn{2}{|c|}{ Mean } & $\begin{array}{l}62.9 \\
6\end{array}$ & $\begin{array}{l}71.9 \\
6\end{array}$ & 79.54 \\
\hline \multicolumn{2}{|c|}{ Standard Deviation } & 6.58 & 7.80 & 10.63 \\
\hline \multicolumn{2}{|c|}{ N } & 32 & 33 & 33 \\
\hline
\end{tabular}

From the table, it could be seen of the improvement of the students' tests score. There was a significant improvement between the mean scores in pre-test and Cycle I test. The gap in these two tests was 9, which the most improvement was in the good category, from 3 students in the pre-test to 12 students in the Cycle I test. Meanwhile, there was also an improvement from the mean score in Cycle I test and Cycle II test, with the gap was 7.58. The very much improvement was in the very good category between the result in Cycle I test and Cycle II test, increasing from 3 students to 14 students or 11 students' difference. Moreover, about two students could get Very Good category in the Cycle II result. Therefore, it could be surely said that the use of the memes did improve students' writing creativity with the result as provided above.

The Wilcoxon signed-rank-test was also done in order to find out whether there were significant differences between the pre- and post-test groups or not as shown in the following table:

Table 3. Wilcoxon Signed-Rank-Test Result

\begin{tabular}{|l|l|}
\hline & Pre-Test and Cycle II Test \\
\hline $\mathbf{Z}$ & $-4,671^{\mathrm{b}}$ \\
\hline Asymp. Sig (2-tailed) &, 000 \\
\hline
\end{tabular}

The table above shows that the result is in 0,000 in Asymp. Sig. (2-tailed). It is indicated that the result was $<0,05$, which means that there was no significant difference between the group of pre-test and cycle II test or post-test.

The writer and the collaborator did rate the students work to get the interrater reliability. It was done to measure whether the writer and the collaborator had the same perspective in assessing and scoring the students or not. The following is the result of the interrater reliability: 
Table 4. The Interrater Reliability Result

\begin{tabular}{|l|l|l|l|}
\hline & \multicolumn{1}{|c|}{ Value } & \multicolumn{1}{|c|}{$\begin{array}{c}\text { Asymptotic } \\
\text { Standard Error }\end{array}$} & Approximate T \\
\hline $\begin{array}{l}\text { Measurement of } \\
\text { Agreement Kappa }\end{array}$ &, 677 &, 098 & 7,427 \\
\hline N of Valid Cases & 32 & \multicolumn{2}{|l}{} \\
\hline
\end{tabular}

It was shown that the kappa coefficient was 0,677. It means that the writer and the collaborator had the same perspective in rating the tests. Therefore, the validity could be fulfilled as the writer, and the collaborator could score the tests approximately the same.

Next, the influence of the students' brain quotient tests results would be thoroughly described. The writer would present the relation between the students' brain quotient tests and students' writing tests results. The data would be divided into three categories, namely high, middle, and low scores with each of it consisted of the first three students who got the highest writing tests in each category. The high category was the students who got a total score of $>240$ for high, $>210$ for middle, and the rest was for the low category.

The first one is the high category. The students in this category were those who got more than 240 in the total score of pre-, Cycle I, and Cycle II tests. The following is the data of the high category:

Table 5. The High Category

\begin{tabular}{|c|c|c|c|c|c|}
\hline Student & Pre-Test & $\begin{array}{c}\text { Cycle I } \\
\text { Test }\end{array}$ & $\begin{array}{c}\text { Cycle II } \\
\text { Test }\end{array}$ & $\begin{array}{c}\text { Brain } \\
\text { Quotient } \\
\text { Test }\end{array}$ & $\begin{array}{c}\text { Marked } \\
\text { Brain Bias }\end{array}$ \\
\hline Student 1 & 75 & 90 & 90 & Good & Right-Brain \\
\hline Student 2 & 75 & 85 & 95 & Good & Right-Brain \\
\hline Student 3 & 75 & 85 & 90 & Very Good & Left-Brain \\
\hline
\end{tabular}

It could be seen that from the above table, the students in the high score category had all at least good brain quotient test result. Also, all of them were right-brain bias. The student who got the two highest scores, Student 1 and Student 2 were in the good category in brain quotient test. Student 3, who got the least, surprisingly was in the very good category in the brain quotient test, while he also was a left-brain person. What it could be said was that all of the students in the high category had all at least good category in brain result and had brain bias, whether it was right-/left-brain bias.

The next one is the middle category. Students in this category were whom the scores of pre-, cycle I, and cycle II tests got more than 210 but less than 240 . Here is the table containing the data:

Table 6. The Middle Category 


\begin{tabular}{|c|c|c|c|c|c|}
\hline Student & Pre-Test & $\begin{array}{c}\text { Cycle I } \\
\text { Test }\end{array}$ & $\begin{array}{c}\text { Cycle II } \\
\text { Test }\end{array}$ & $\begin{array}{c}\text { Brain } \\
\text { Quotient } \\
\text { Test }\end{array}$ & $\begin{array}{c}\text { Marked } \\
\text { Brain Bias }\end{array}$ \\
\hline Student 4 & 70 & 75 & 85 & Good & No Marked \\
\hline Student 5 & 70 & 75 & 80 & Good & No Marked \\
\hline Student 6 & 70 & 70 & 85 & Average & No Marked \\
\hline
\end{tabular}

There was no brain bias in this category which meant they were in the middle of the left and right brain bias. Those who got average brain quotient tended to be the middle-low category, in which they were very close to the low category. It could be seen from Student 6 ' scores that only got 225 in the total score. He also only got average in brain quotient test. On the other hand, Student 4 and 5 had the good category in the test. It could be concluded that those who got the good category in brain quotient test might not always be got the high score in the writing tests, but for those who got average in the brain quotient test were not in the high category.

The last one is the low category. Here, the students were those who got less than 210 in total scores of the writing tests. The following is the data in this category:

Table 7. The Low Category

\begin{tabular}{|c|c|c|c|c|c|}
\hline Student & Pre-Test & $\begin{array}{c}\text { Cycle I } \\
\text { Test }\end{array}$ & $\begin{array}{c}\text { Cycle II } \\
\text { Test }\end{array}$ & $\begin{array}{c}\text { Brain } \\
\text { Quotient } \\
\text { Test }\end{array}$ & $\begin{array}{c}\text { Marked } \\
\text { Brain Bias }\end{array}$ \\
\hline Student 7 & 65 & 70 & 55 & Average & No Marked \\
\hline Student 8 & 55 & 60 & 65 & Average & No Marked \\
\hline Student 9 & 55 & - & 55 & $\begin{array}{c}\text { Below } \\
\text { Average }\end{array}$ & No Marked \\
\hline
\end{tabular}

From the table, it could be seen that there was no good category in brain quotient, even there was one student who got below average. The first two, Student 7 and Student 8, were only in the average category. Student 9 even got no improvement in his scores and only carried out two out of three tests. The students in this category also had no marked brain bias. This could be said that those who got average brain quotient test could be in the low category; even worse for those who got below average in the brain quotient test.

To conclude, the brain quotient result did have a relation to the students' scores. The conclusion could be summarized up as in the following table:

Table 8. The Conclusion Findings in Brain Quotient Test Results 


\begin{tabular}{|c|c|c|}
\hline $\begin{array}{c}\text { Brain } \\
\text { Quotient } \\
\text { Result }\end{array}$ & $\begin{array}{c}\text { Marked } \\
\text { Brain Bias }\end{array}$ & $\begin{array}{c}\text { Writing Tests } \\
\text { Category }\end{array}$ \\
\hline Very Good & Left-/Right- & High \\
\hline Good & Left- & High \\
\hline Average & No Marked & Middle \\
\hline $\begin{array}{c}\text { Below } \\
\text { Average }\end{array}$ & No Marked & Low \\
\hline
\end{tabular}

Students who got at least good category tended to have good scores in their writing tests. On the other hands, the students who got average even below average tended to have bad scores in their writing tests. It could be said that creative thinking did affect the writing creativity results. Meanwhile, for the brain bias, it did not affect too much unless the students got a marked brain bias, whether it was left or right. As it could be seen, all of the students in the high category had a brain bias. The students who got a marked brain bias tended to be more active, creative, and critical that was proven by their scores on their writing tests results. However, it also could not be said that the students who got no marked brain bias tended to get bad scores. Some students in the middle category had no marked brain bias, as well. Thus, the marked brain bias only had an effect when the students had whether left- or right-brain bias

\section{CONCLUSION}

The actions implemented were successfully fulfilled the research's objectives. The use of the memes could efficiently be used for improving students' writing creativity. It could be said efficiently because the memes could be used in two sessions. The thing that should be considered more was the humorous aspects. The teacher could use the memes for the warming up to open the students' mind. Oppositely, in the end, the memes could also be used for the cooling down as the humorous aspects could make the students enjoy while reduced their anxiety. The use of the meme pictures could activate students' creative thinking as well as critical thinking. It was indicated by the students' activeness in participating in the discussion. Moreover, they also could change their perspective towards the topics given. They could widely open their minds to look at the other sights. The meme pictures could drive students' mind to the next level of their thinking. They could think creatively while also critically in the discussion 
session. However, to use the memes, the teacher should carefully choose the appropriate memes. It was because some memes were violent, or even made for adults.

This research is still exploring only the surface. There are more things that can be explored on the memes. In addition, it is suggested to use suitable memes based on the conventions with the students to be involved in the research.

\section{REFERENCES}

[1] R. Kern, Literacy and Language Teaching, Oxford: Oxford University Press, 2000.

[2] J. Harmer, How to Teach Writing, Essex: Pearson Education Limited, 2004.

[3] R. Dawkins, The Selfish Gene, Oxford: Oxford University Press, 2006.

[4] B. Buchel, „Internet Memes as means of Communication,“ Masaryk University, Brno, 2012.

[5] D. Morley, The Cambridge Introduction to Creative Writing, New York: Cambridge University Press, 2007.

[6] J. A. S. Navera, L. A. B. Garinto a P. N. M. Valdez, „Teaching Against the Meme: Politics, Argumentation and Engagement in an ESL Classroom in the Philippines, “The Journal of Asia TEFL, v. 16, pp. 393-400, 2019.

[7] W. Hiew, ,The Effectiveness of Using Literature Response Journal to Improve Students' Writing Fluency,“ Journal of Arts, Science and Commerce, v. 1, pp. 27-39, 2010.

[8] A. D. Purnama, „Incorporating Memes and Instagram to Enhance Student's Participation,“ Language and Language Teaching Journal, v. 20, pp. 1-14, 2017.

[9] G. Brown, „Web Culture: Using Memes to Spread and Manipulate Ideas on a Massive Scale,“ The Journal of Education, Community and Values, v. 13, pp. 187-193, 2013.

[10] N. Veerasamy a W. A. Labuschagne, „Increasing and Visualising Meme Effectiveness,“ Journal of Information Warfare, v. 13, pp. 97-112, 2014.

[11] S. Kemmis, R. McTaggart a R. Nixon, The Action Research Planner, Singapore: Springer, 2013.

[12] M. B. Miles, A. M. Huberman a J. Saldana, Qualitative Data Analysis, California: SAGE Publications Inc, 2014. 